\title{
Resiliency of juvenile walleye pollock to projected levels of ocean acidification
}

\author{
Thomas P. Hurst ${ }^{1, *}$, Elena R. Fernandez ${ }^{2,5}$, Jeremy T. Mathis ${ }^{2,6}$, Jessica A. Miller ${ }^{3}$, \\ Charlotte M. Stinson ${ }^{4}$, Ernestine F. Ahgeak ${ }^{4}$
}

${ }^{1}$ Fisheries Behavioral Ecology Program, Resource Assessment and Conservation Engineering Division, Alaska Fisheries Science Center, National Marine Fisheries Service, National Oceanic and Atmospheric Administration, Hatfield Marine Science Center, Newport, Oregon 97365, USA

${ }^{2}$ School of Fisheries and Ocean Sciences, University of Alaska, Fairbanks, Alaska 99775, USA

${ }^{3}$ Department of Fisheries and Wildlife, Coastal Oregon Marine Experiment Station, Hatfield Marine Science Center, Oregon State University, Newport, Oregon 97365, USA

${ }^{4}$ Hatfield Marine Science Center, Oregon State University, Newport, Oregon 97365, USA

${ }^{5}$ Present address: Alaska Department of Fish and Game, PO Box 669, Cordova, Alaska 99574, USA

${ }^{6}$ Present address: Pacific Marine Environmental Laboratory, National Oceanic and Atmospheric Administration, Seattle, Washington 98115, USA

\begin{abstract}
As atmospheric concentrations of $\mathrm{CO}_{2}$ rise, the $\mathrm{pH}$ of high-latitude oceans is predicted to decrease by 0.3 to 0.5 units by 2100 . Several biological consequences of ocean acidification across this $\mathrm{pH}$ range have already been documented in invertebrates and tropical marine fishes. However, little work has been done examining potential responses of the temperate and boreal marine fish species that support major fisheries. In 2 experiments, we examined the growth responses of juvenile walleye pollock Theragra chalcogramma at ambient and 3 elevated $\mathrm{CO}_{2}$ levels. In a short-term experiment with yearlings, $\mathrm{CO}_{2}$ treatment had no significant effect on growth or condition after 6 wk of rearing. Elevated $\mathrm{CO}_{2}$ levels $(>450 \mu \mathrm{atm})$ increased the rate of otolith deposition, but did not affect otolith elemental composition. In a second experiment, growth in length of sub-yearlings over $12 \mathrm{wk}$ at $8^{\circ} \mathrm{C}$ was $7.2 \%$ faster in the 2 higher $\mathrm{CO}_{2}$ treatments $(>1200 \mu \mathrm{atm})$ than in the lower $\mathrm{CO}_{2}$ treatments $(<900 \mu \mathrm{atm})$. Growth of sub-yearlings measured during 11 subsequent weeks of rearing at $2.5^{\circ} \mathrm{C}$ did not differ among $\mathrm{CO}_{2}$ treatments. There was no effect of $\mathrm{CO}_{2}$ treatment on condition factor following either phase of the experiment. Subyearling consumption rates were not directly affected by $\mathrm{CO}_{2}$ treatment, confirming that growth at elevated $\mathrm{CO}_{2}$ levels is not maintained through compensatory feeding. While not exhaustive of potential interactive environmental factors, these experiments demonstrate a general resiliency of growth energetics in juvenile walleye pollock to the direct effects of $\mathrm{CO}_{2}$ changes predicted for the Gulf of Alaska and Bering Sea in the next century.
\end{abstract}

KEY WORDS: Ocean acidification - Hypercapnia - Growth rate - Consumption · Otolith · Temperature Resale or republication not permitted without written consent of the publisher

\section{INTRODUCTION}

Ocean acidification is a global phenomenon caused by the release of terrestrially sequestered $\mathrm{CO}_{2}$ into the atmosphere through the burning of fossil fuels and changes in land use practices. Approximately one-third of anthropogenically released $\mathrm{CO}_{2}$ has dissolved into the ocean (Feely et al. 2004, Sabine et al. 2004, Orr et al. 2005). The dissolution of $\mathrm{CO}_{2}$ into ocean waters results in a decrease of $\mathrm{pH}$ and reduces the availability of carbonate ions. High-latitude ecosystems are predicted to be most impacted by on- 
going ocean acidification due to the high solubility of $\mathrm{CO}_{2}$ at low temperatures as well as these systems' unique circulation patterns (Byrne et al. 2010) and biogeochemical processes (Fabry et al. 2009, Mathis et al. 2011a,b). High-latitude oceans are projected to experience $\mathrm{pH}$ declines of up to 0.45 units during the next century, causing large regions to be consistently undersaturated with respect to aragonite (YamamotoKawai et al. 2009, Steinacher et al. 2009). These highlatitude regions, including the Bering Sea and Gulf of Alaska, are highly productive ecosystems that support important commercial seafood resources and will likely be impacted to some degree by ocean acidification (Cooley \& Doney 2009).

Experimental evidence is accumulating that elevated $\mathrm{CO}_{2}$ concentrations ('environmental hypercapnia') and depressed $\mathrm{pH}$ can have a variety of effects on the growth and development of marine organisms (Fabry et al. 2008, Kroeker et al. 2010), but both the magnitude and direction of these effects will likely vary among species, trophic groups, and ontogenetic stages (Ries et al. 2009, Kroeker et al. 2010). It has been suggested that their high metabolic capacity and ability to maintain intra- and extracellular acidbase status will allow most marine fishes to physiologically cope with projected levels of ocean acidification (Pörtner et al. 2004, Melzner et al. 2009b). While studies on the growth rates of juvenile fishes generally support this perspective, there are few empirical examples of $\mathrm{CO}_{2}$ responses of marine fishes relevant to the issue of ocean acidification (see review by Ishimatsu et al. 2008). Conversely, recent studies have demonstrated that the embryonic and larval stages of fishes may be more vulnerable to the effects of ocean acidification (Baumann et al. 2012, Frommel et al. 2012). Other experiments have demonstrated effects of elevated $\mathrm{CO}_{2}$ on otolith growth (Checkley et al. 2009, Munday et al. 2011b), and it is unknown whether these effects are restricted to the larval stage. Furthermore, elemental incorporation in biogenic carbonates is influenced by $\mathrm{pH}$ (Al-Horani et al. 2003, Gaetani \& Cohen 2006). Therefore, one would expect that changes in ambient $\mathrm{pH}$ could alter rates of elemental incorporation into the calcium carbonate matrix of fish otoliths. It is not yet clear what, if any, effect reduced $\mathrm{pH}$ will have on elemental incorporation in fish otoliths and how varied the response is among species. Additional empirical work is needed to determine the range of responses and ontogenetic patterns of sensitivity of marine fishes to projected ocean acidification, especially among the temperate and boreal species that support much of the world's fishery production.
Walleye pollock Theragra chalcogramma are abundant over shelf and slope areas of the North Pacific Ocean and Bering Sea and extend to the south through the coastal waters of British Columbia (Canada) and Puget Sound. In the USA, harvests have averaged more than $1.1 \mathrm{Mt}$ over the past decade and represent the largest single-species fishery in the nation. In addition to their economic importance, walleye pollock are a critical prey species for numerous marine birds and mammals (Livingston 1993). The degree of exposure of a species to natural (non-anthropogenic), diurnally or seasonally elevated $\mathrm{CO}_{2}$ levels has been suggested as a potential factor in determining species' relative sensitivity to future ocean acidification conditions (Denman et al. 2011, Munday et al. 2011a). In late winter, walleye pollock spawn at depth (usually $>50 \mathrm{~m}$ ) and eggs drift at depth ( 200 $\mathrm{m}$ in the Gulf of Alaska, Brodeur \& Wilson 1996) or rise to the surface (Smart et al. 2012). Juveniles are pelagic, inhabiting surface and sub-surface waters over the continental shelf as well as shallow coastal waters (Brodeur \& Wilson 1996). With their midwater spawning and pelagic larval and juvenile distributions, walleye pollock are exposed to relatively stable physiochemical environments. Such a life history may render them more sensitive to ocean acidification than other North Pacific resource species with demersal spawning or which inhabit shallow subtidal nursery areas (Munday et al. 2011a).

In the present study, we examined the direct effects of projected ocean acidification on juvenile walleye pollock. To provide an ontogenetic perspective on $\mathrm{CO}_{2}$-sensitivity among early life history stages, a companion study examined the effects of elevated $\mathrm{CO}_{2}$ levels on egg and larval walleye pollock (T. Hurst unpubl.). Because of the direct linkage of growth energetics to population productivity, these experiments were focused on determining the growth, feeding, condition, and survival responses of juvenile walleye pollock to elevated $\mathrm{CO}_{2}$ levels. In one experiment, 'yearling' (age-1) walleye pollock were reared for 6 wk to evaluate short-term responses in growth and condition, and the potential for hypercapnia-induced changes in otolith accretion and elemental composition. In a second experiment, 'sub-yearling' (age-0) walleye pollock were reared under elevated $\mathrm{CO}_{2}$ conditions for $28 \mathrm{wk}$ to describe the cumulative effects of prolonged exposure to elevated $\mathrm{CO}_{2}$ levels. The second experiment included seasonally-reflective warm and cold phases and evaluated the possibility that growth rates are maintained in the face of elevated metabolic costs through compensatory feeding. Treatments were selected to 
reflect ambient conditions and conditions predicted to occur in high latitude seas in the next century (400 to $600 \mu \mathrm{atm}$ increase). A high $\mathrm{CO}_{2}$ treatment (>1200 $\mu \mathrm{atm}$ increase) was included to evaluate physiological sensitivity over a broader range of conditions than those predicted for ocean acidification.

\section{MATERIALS AND METHODS}

\section{Rearing system}

A system was developed for the rearing of marine fish eggs, larvae, and juveniles under controlled temperatures and $\mathrm{CO}_{2}$ levels (Fig. 1). A pH probe (Ag/ $\mathrm{AgCl}$ electrode) in the conditioning tank was used to regulate the injection of $\mathrm{CO}_{2}$ to achieve the highest $\mathrm{CO}_{2}$ treatment. When $\mathrm{pH}$ was above the target condition, a solenoid valve opened, introducing $\mathrm{CO}_{2}$ into the conditioning tank through a fluid-gas membrane contactor. The $\mathrm{CO}_{2}$-conditioned water was then pumped to a series of 3 header tanks where it was mixed in fixed proportions with ambient seawater to achieve the $3 \mathrm{CO}_{2}$ treatments. An additional header tank received only ambient seawater. Water from the elevated header tank for each treatment gravity-fed 4 (16 tanks total) $100 \mathrm{l}$ treatment tanks. Water temperatures were controlled by mixing ambient temperature water with chilled seawater in the conditioning tank prior to $\mathrm{CO}_{2}$ injection or pumping to

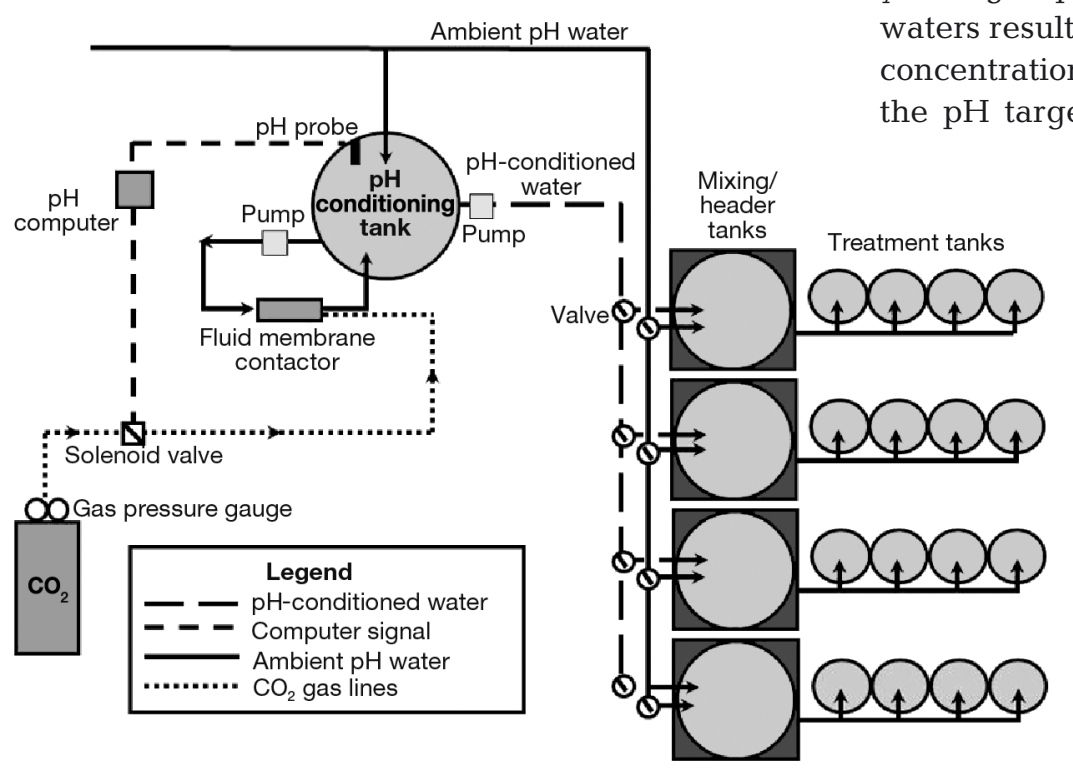

Fig. 1. Schematic of flow-through system developed for rearing marine fish under ocean acidification conditions. Note that during these experiments, 1 mixing/header tank each received only ambient seawater or high $\mathrm{CO}_{2}$ seawater. In the sub-yearling experiment, only 3 of the treatment tanks were used elevated header tanks. The outflow from 1 treatment tank in each treatment was diverted past a benchtop meter (VWR SympHony meter SB80PD) with $\mathrm{pH}$ and temperature probes for monitoring. Temperature and $\mathrm{pH}$ were recorded every 15 to $30 \mathrm{~min}$ throughout the experiment. Monitoring $\mathrm{pH}$ probes were calibrated approximately weekly using NBS calibration standards of $\mathrm{pH} 4.0,7.0$, and 10.0.

To describe the carbonate parameters of water in the experiments, water samples were taken 1 to 2 times per week from each treatment. Seawater samples were drawn into pre-cleaned $300 \mathrm{ml}$ Pyrex bottles, treated with $\mathrm{HgCl}_{2}$ to halt biological activity, sealed, and then sent to the analytical laboratory at the University of Alaska at Fairbanks. These water samples were analyzed for dissolved inorganic carbon (DIC) and total alkalinity (TA) using a VINDTA 3C (Versatile INstrument for the Determination of dissolved inorganic carbon and Total Alkalinity) coupled to a UIC 5014 coulometer. These data were used to calculate the $\mathrm{pH}, \mathrm{pCO}_{2}$, and carbonate mineral saturation states $(\Omega)$ of the water using the program developed by Lewis \& Wallace (1998).

Experiments were conducted with 4 treatments (ambient, low, medium, and high $\mathrm{CO}_{2}$ ). Targets for the manipulated $\mathrm{CO}_{2}$ treatments were $0.1,0.3$, and $0.7 \mathrm{pH}$ units below the average ambient condition ( 8.05). Measured conditions are presented in Table 1. The main departure from targeted conditions occurred during the warm phase of the subyearling experiment when local upwelling of deep waters resulted in periodic increases in ambient $\mathrm{CO}_{2}$ concentration to $>700 \mu \mathrm{atm}$. During these periods, the $\mathrm{pH}$ targets of the manipulated $\mathrm{CO}_{2}$ treatments were adjusted to maintain separation between treatments, resulting in higher $\mathrm{CO}_{2}$ levels across all treatments (Table 1).

\section{Yearling growth experiment}

Walleye pollock were captured at age- 0,10 to $20 \mathrm{~mm}$ total length $\left(L_{\mathrm{T}}\right)$, from nearshore waters of Puget Sound at Port Townsend, Washington (USA), with a lighted lift net suspended from a dock. Fish were held for at least $24 \mathrm{~h}$ in ambient seawater prior to shipment to the Alaska Fisheries Science Center's laboratory in Newport, Oregon. Fish were reared in groups at 8 to $9^{\circ} \mathrm{C}$ for 18 mo prior to use in the experi- 
Table 1. Theragra chalcogramma. Conditions during experiments exposing early life stages of walleye pollock to projected ocean acidification (mean $\pm \mathrm{SD}$ ). Carbonate system parameters (dissolved inorganic carbon, DIC; total alkalinity, TA) were measured 2 to 3 times $\mathrm{wk}^{-1}$ and used to calculate $\mathrm{pH}, \mathrm{pCO}_{2}$, and $\Omega_{\text {Aragonite. }}$. Seasonal upwelling caused periodic elevation in ambient $\mathrm{CO}_{2}$ during the warm phase of the experiment. Target conditions in other treatments were adjusted to maintain differences between treatments

\begin{tabular}{|c|c|c|c|c|c|c|}
\hline Experiment & $\begin{array}{c}\text { Temperature } \\
\left({ }^{\circ} \mathrm{C}\right)\end{array}$ & $\begin{array}{c}\text { DIC } \\
\left.(\mu \mathrm{mol} \mathrm{kg})^{-1}\right)\end{array}$ & $\begin{array}{c}\text { TA } \\
\left.(\mu \mathrm{mol} \mathrm{kg})^{-1}\right)\end{array}$ & $\begin{array}{c}\mathrm{pH} \\
\text { (seawater scale) }\end{array}$ & $\begin{array}{c}\mathrm{pCO}_{2} \\
\text { ( } \mu \text { atm) }\end{array}$ & $\Omega_{\text {Aragonite }}$ \\
\hline \multicolumn{7}{|l|}{ Yearlings } \\
\hline Ambient & $8.7 \pm 0.3$ & $2072.2 \pm 14.7$ & $2209.3 \pm 6.5$ & $8.02 \pm 0.04$ & $414 \pm 45$ & $1.64 \pm 0.13$ \\
\hline Low & $8.9 \pm 0.3$ & $2091.9 \pm 11.7$ & $2210.5 \pm 4.7$ & $7.97 \pm 0.04$ & $478 \pm 50$ & $1.47 \pm 0.11$ \\
\hline Medium & $8.8 \pm 0.3$ & $2159.2 \pm 21.9$ & $2213.3 \pm 6.0$ & $7.76 \pm 0.08$ & $815 \pm 167$ & $0.97 \pm 0.16$ \\
\hline High & $8.7 \pm 0.3$ & $2262.3 \pm 13.9$ & $2221.0 \pm 5.9$ & $7.43 \pm 0.05$ & $1805 \pm 212$ & $0.46 \pm 0.05$ \\
\hline \multicolumn{7}{|c|}{ Sub-yearlings: warm phase } \\
\hline Ambient & $8.3 \pm 0.7$ & $2116.9 \pm 45.0$ & $2211.5 \pm 5.9$ & $7.89 \pm 0.13$ & $596 \pm 178$ & $1.28 \pm 0.36$ \\
\hline Low & $8.2 \pm 0.7$ & $2161.9 \pm 25.7$ & $2211.1 \pm 7.7$ & $7.74 \pm 0.07$ & $828 \pm 144$ & $0.92 \pm 0.16$ \\
\hline Medium & $8.2 \pm 0.7$ & $2216.0 \pm 25.4$ & $2214.8 \pm 5.0$ & $7.57 \pm 0.09$ & $1285 \pm 321$ & $0.62 \pm 0.11$ \\
\hline High & $8.3 \pm 0.8$ & $2334.6 \pm 20.0$ & $2223.8 \pm 3.9$ & $7.23 \pm 0.05$ & $2894 \pm 343$ & $0.29 \pm 0.03$ \\
\hline \multicolumn{7}{|c|}{ Sub-yearlings: cold phase } \\
\hline Ambient & $2.4 \pm 0.5$ & $2002.9 \pm 27.9$ & $2199.8 \pm 8.0$ & $8.24 \pm 0.06$ & $225 \pm 35$ & $2.13 \pm 0.26$ \\
\hline Low & $2.4 \pm 0.6$ & $2088.2 \pm 52.0$ & $2209.1 \pm 6.5$ & $8.05 \pm 0.13$ & $386 \pm 112$ & $1.46 \pm 0.45$ \\
\hline Medium & $2.4 \pm 0.5$ & $2161.6 \pm 31.3$ & $2216.6 \pm 3.4$ & $7.85 \pm 0.10$ & $643 \pm 169$ & $0.94 \pm 0.21$ \\
\hline High & $2.4 \pm 0.5$ & $2272.3 \pm 23.8$ & $2224.2 \pm 5.6$ & $7.48 \pm 0.08$ & $1543 \pm 293$ & $0.42 \pm 0.09$ \\
\hline
\end{tabular}

ment. Initially, fish were fed thawed krill Euphausia pacifica daily. Later, feeding was reduced to 3 times weekly, and krill was supplemented with a gelatinized combination of squid, krill, herring, commercial fish food, amino acid supplements and vitamins ('gel food'). As fish grew, they were transferred to $5678 \mathrm{l}$ tanks, and feeding was further reduced to twice weekly. To initiate the experiment, 3 fish were transferred from the rearing tanks to each of 4 tanks in each $\mathrm{CO}_{2}$ treatment (16 tanks total). After $7 \mathrm{~d}$ of tank acclimation in ambient $\mathrm{CO}_{2}$ conditions, all fish were weighed (wet mass, $M_{\mathrm{W}}$, to $0.1 \mathrm{~g}$ ) and measured ( $L_{\mathrm{T}}$ to $1.0 \mathrm{~mm}$ ), and treatments were adjusted to $\mathrm{pH}$ targets over $2 \mathrm{~d}$. Throughout the experiment, temperatures were maintained at $9^{\circ} \mathrm{C}$. Initial size of fish used in the experiment was $209.3 \pm 11.9(\mathrm{SD}) \mathrm{mm} L_{\mathrm{T}}$ and $72.0 \pm$ $12.4 \mathrm{~g}$ wet weight. There were no significant differences in initial size among the treatments (length $F_{3,43}=1.960, \mathrm{p}=0.134$; weight $F_{3,43}=0.963, \mathrm{p}=$ $0.419)$. Throughout the experiment, fish were fed gel food to satiation (cessation of feeding) once a day. After 6 wk of rearing, all fish were captured, weighed, measured, and sacrificed. Otoliths were removed and preserved for analysis of increment width and elemental composition. Livers were removed and weighed $\left(M_{\mathrm{L}}\right.$ to $\left.0.01 \mathrm{~g}\right)$ for calculation of the hepatosomatic index $\left(I_{\mathrm{H}}\right)$, reflecting variation in lipid storage and nutritional condition.

Growth rates in length $\left(g_{\mathrm{L}}\right.$, in $\left.\mathrm{mm} \mathrm{d}^{-1}\right)$ and mass (weight-specific growth $\left[g_{\mathrm{M}}\right], \mathrm{d}^{-1}$ ) of each fish were determined based on change in size between initial and final measurements. Although fish were not individually marked, size variation within each tank allowed easy identification of individuals. A whole body condition index $\left(I_{C}\right)$ was calculated using the residual weight method (Blackwell et al. 2000). Individual fish condition was expressed as the deviation from the relationship between $\log _{10}\left(M_{\mathrm{W}}\right)$ and $\log _{10}\left(L_{\mathrm{T}}\right)$ based on all experimental fish. Similarly, $I_{\mathrm{H}}$ expressed individual deviation from the relationship between $\log _{10}\left(M_{\mathrm{L}}\right)$ and $\log _{10}\left(L_{\mathrm{T}}\right)$. For statistical analyses, fish metrics were pooled across replicate tanks, as preliminary analyses indicated no significant differences among tanks within $\mathrm{CO}_{2}$ treatments (all $\mathrm{p}$ > $0.05)$. Growth rates and condition indices were analyzed across $\mathrm{CO}_{2}$ treatments with a 1-way ANOVA.

\section{Yearling otolith analysis}

Otoliths were stored dry prior to analysis. Otoliths were ultrasonically cleaned in NANOpure ${ }^{\circledR}$ (18 megaohm) water for $15 \mathrm{~min}$, dried under Class 100 clean conditions to prevent contamination, and stored dry in acid-washed plastic trays. The left otolith from each fish was embedded in resin (Polytranspar ${ }^{\mathrm{TM}}$ ), sectioned on the transverse plane using an IsoMet ${ }^{\circledR}$ low-speed diamond blade saw (BUEHLER ${ }^{\circledR}$ ), and polished with lapping film and $\mathrm{AlO}_{2}$ powder $(0.3 \mu \mathrm{m})$. Right otoliths were used when the left otolith was missing or broken. Polished otoliths were photographed under a com- 
pound microscope at $1000 \times$ magnification. ImagePro ${ }^{\circledR}$ was used to identify and measure the widths $(\mu \mathrm{m})$ of daily growth increments at the edge of the otolith along the ventral edge (corresponding to the experimental period). However, as observed in other fish in laboratory culture, daily increments were indistinct in many fish and could not be unambiguously read. We were able to unambiguously measure a series of at least 10 consecutive increments in 20 fish across treatments.

Otolith elemental composition ( $\mathrm{Mg}, \mathrm{Ca}, \mathrm{Mn}, \mathrm{Sr}$, and $\mathrm{Ba}$ ) was quantified using a VG PQ ExCell inductively coupled plasma mass spectrometer with a New Wave DUV193 excimer laser at Oregon State University's WM Keck Collaboratory for Plasma Spectrometry. Background levels of all analytes were measured before ablation and subtracted from measurements during ablation. Analytes were measured along a transect along the ventral edge that was parallel to growth increments. A pre-ablation was completed with a $100 \mu \mathrm{m}$ spot size at $1 \mathrm{~Hz}$ and $100 \mu \mathrm{m} \mathrm{s}^{-1}$. For data collection, the laser was set at a $50 \mu \mathrm{m}$ spot size, $6 \mathrm{~Hz}$, and translated across the sample at $5 \mu \mathrm{m} \mathrm{s}^{-1}$. Normalized ion ratios (e.g. Mg:Ca) were converted to concentration based on measurements of National Institute of Standards and Technology (NIST) 612 standard glass and are presented as molar ratios (Miller 2009). The mean percent relative standard deviations (\%RSD) for NIST 612 standard glass during analyses were: ${ }^{24} \mathrm{Mg}=4.3,{ }^{43} \mathrm{Ca}=3.0$, ${ }^{55} \mathrm{Mn}=3.8{ }^{86} \mathrm{Sr}=6.7$, and ${ }^{138} \mathrm{Ba}=4.1$. A calcium carbonate standard (USGS MACS-1) was used to assess accuracy of $\mathrm{Mn}, \mathrm{Sr}$, and $\mathrm{Ba}$, which were all within $10 \%$ of reported values.

We collected data on water chemistry to confirm that elemental concentrations of rearing waters were not altered by the process of $\mathrm{CO}_{2}$ level manipulation and to calculate elemental partition coefficients to more accurately determine whether there were detectable changes in the rates of elemental incorporation among $\mathrm{CO}_{2}$ treatments (Morse \& Bender 1990). Weekly water samples were collected from each $\mathrm{CO}_{2}$ treatment throughout the experiment. Water samples were analyzed with a Leeman-Teledyne inductively coupled plasma-optical emission spectrometer according to the methods of DiMaria et al. (2010). Partition coefficients $(D)$ were then calculated for $\mathrm{Mg}, \mathrm{Mn}, \mathrm{Sr}$, and $\mathrm{Ba}$ using individual otolith elemental ratios (e.g. $\mathrm{Mg}: \mathrm{Ca}_{\text {otolith }}$ ) and mean tank water ratios $\left(\mathrm{Mg}: \mathrm{Ca}_{\text {water }}\right)$. Otolith elemental ratios and partition coefficients were analyzed with a 1 -way ANOVA across $\mathrm{CO}_{2}$ treatments.

\section{Sub-yearling growth and feeding experiment}

Age-0 walleye pollock were captured from nearshore nursery grounds and transported to and reared in the laboratory as described above. Six weeks after capture, fish were removed from the rearing tanks, measured ( $L_{\mathrm{T}}$ to $1.0 \mathrm{~mm}$ ), and weighed ( $M_{\mathrm{W}}$ to $\left.0.01 \mathrm{~g}\right)$, and 10 fish were introduced into each of 12 experimental treatment tanks held at ambient $\mathrm{pH}$. Prior to stocking, fish were loosely sorted by size in order to minimize the potential for intra-cohort cannibalism frequently observed in larval and juvenile gadids (Folkvord \& Otterå 1993). As a result, there were significant differences in initial size among replicates within treatments (length and mass $\mathrm{p}<0.01$ ), but not between treatments (both $\mathrm{p}>0.9$ ). This variation in size was small compared to the amount of growth occurring over the experiment; therefore, the 3 tanks are considered treatment replicates in these analyses (with initial mean size included as a covariate where necessary). Initial mean \pm SD sizes of fish used in the experiment were $47.7 \pm 5.1 \mathrm{~mm}$ and $0.63 \pm 0.25 \mathrm{~g}$. During the first $4 \mathrm{~d}$ after measurement and stocking (tanks at ambient $\mathrm{pH}$ ), several fish died and were replaced with remaining fish from the holding tanks. On Days 4 to 6 of the experiment, pH levels of the experimental tanks were adjusted to treatment targets. Fish that died later in the experiment $(n=7)$ were not replaced and were excluded from growth rate calculations.

Fish were reared for $12 \mathrm{wk}$ at $8^{\circ} \mathrm{C}$ ('warm phase'). During this phase, fish were fed to apparent satiation once a day with thawed krill ( 3 times $\mathrm{wk}^{-1}$ ) or gel food (4 times $\mathrm{wk}^{-1}$ ). Tank temperatures were checked twice each day and maintained at $8^{\circ} \mathrm{C}$. At the end of the warm phase, water temperatures were lowered to a target temperature of $2.5^{\circ} \mathrm{C}$ over a period of $7 \mathrm{~d}$. Fish were reared at $2.5^{\circ} \mathrm{C}$ for an additional 15 wk ('cold phase'), for a cumulative experimental exposure of 28 wk. During the cold phase, feeding was reduced to 3 times $\mathrm{wk}^{-1}$ (thawed krill once per week; gel food twice per week). Data on growth and consumption (see below) during the first 4 wk of the cold phase were not included to allow for thermal acclimation.

Growth rates were measured by weighing and measuring all fish in the experiment at $14 \mathrm{~d}$ intervals during the warm phase of the experiment and at $21 \mathrm{~d}$ intervals during the cold phase. Mean growth rate of fish in each replicate tank was used as the level of observation in statistical analyses. Tank means were calculated from individual growth trajectories of fish within the tank. Although growth rates of individual fish within each replicate 
tank were not used in the analyses, the calculation of individual trajectories provided an additional check on patterns of growth variation among replicates and treatments. Because fish were too small to mark individually, we assumed that size rank was maintained within each replicate tank during the experiment. During each phase of the experiment, the relationship between ln-transformed mass and measurement time was approximately linear, and $g_{\mathrm{M}} \mathrm{d}^{-1}$ was determined by regressing the measurements of $\ln$ (mass) against measurement date for each fish during the 2 phases of the experiment (warm and cold). $g_{\mathrm{L}} \mathrm{mm} \mathrm{d}^{-1}$ was determined by regressing length against date.

Due to the underlying allometry of growth rates among small fishes, there was a significant negative relationship between mean initial mass and tank mean $g_{\mathrm{M}}$ during the warm phase of the experiment (test of initial mass as a covariate, $p=0.002$ ), but this effect was consistent across $\mathrm{CO}_{2}$ treatments (homogeneity of slopes, $\mathrm{p}=0.312$ ). Therefore, tank mean $g_{\mathrm{M}}$ among $\mathrm{CO}_{2}$ treatments was tested using analysis of covariance (ANCOVA) with tank mean initial mass included as a covariate. $g_{\mathrm{L}}$ was similarly tested with mean initial length included as a covariate. During the cold phase of the experiment, $g_{\mathrm{M}}$ and $g_{\mathrm{L}}$ were not correlated with mass at the start of the cold phase (both $\mathrm{p}>0.35$ ). Therefore, differences among $\mathrm{pH}$ treatments were tested with 1-way ANOVA of tank mean growth rate. Similar results were obtained when analyses were conducted with all individual fish growth rates pooled across replicates for each $\mathrm{CO}_{2}$ treatment.

$I_{C}$ was calculated at the end of each phase of the experiment using the residual weight method, as described above. Separate relationships between $\log _{10}\left(M_{\mathrm{W}}\right)$ and $\log _{10}\left(L_{\mathrm{T}}\right)$ were derived for each phase of the experiment, and individual fish condition was expressed as the deviation from the phase-specific regressions. The effect of $\mathrm{CO}_{2}$ treatment on $I_{\mathrm{C}}$ was evaluated with a 1-way ANOVA of mean $I_{\mathrm{C}}$ in each replicate tank.

Consumption rates of fish in each experimental tank were measured once per week throughout the growth experiment (except during the acclimation period at the beginning of the cold phase). Feeding schedule and diet schedules were maintained throughout the experiment to minimize daily variation in consumption rates. Pre-weighed meals of gel food were created for each experimental tank. Food was slowly offered to fish in the tank until they stopped feeding ('apparent satiation'). Food remaining in the meal (unoffered) when the tank reached satiation was weighed. Because of variation in particle size and rapid disintegration of soft foods, we could not estimate the amount of uneaten food remaining in the tank. However, this was minimized by reducing the rate of food addition as fish fed less vigorously. Meals were kept frozen until 15 min prior to feeding and were covered throughout the trial to minimize desiccation of unused food $(<1 \%$ based on replicate, unused meals prepared during each feeding trial). Consumption rates of the 3 tanks in each $\mathrm{pH}$ treatment were measured simultaneously, and $\mathrm{CO}_{2}$ treatments were fed in a randomized order each week. Total consumption in each tank ( $g$ ) was converted to weight-specific consumption rate $\left(C, \mathrm{~g} \mathrm{~g}^{-1}\right)$ based on total fish mass in each tank. Cumulative fish mass in each tank was based on direct measures $3 \mathrm{~d}$ prior to feeding, or interpolated between measurements. Finally, consumption rates during the cold phase of the experiment were converted to daily rates $\left(\mathrm{g} \mathrm{g}^{-1} \mathrm{~d}^{-1}\right)$ to account for the reduced meal frequency (3 times $\mathrm{wk}^{-1}$ ).

$C$ decreased as fish size increased during the warm phase of the experiment (test of mean size as a covariate, $\mathrm{p}<0.01$ ), but this effect was consistent across $\mathrm{CO}_{2}$ treatments (homogeneity of slopes, $\mathrm{p}=$ 0.928). Interestingly, during the cold phase of the experiment, the opposite pattern was observed with consumption rates increasing with increasing body size (test of mean size as a covariate, $\mathrm{p}<0.01$ ). Therefore, weekly measurements of tank consumption rates were corrected to a standard mean fish mass ( $2 \mathrm{~g}$ in warm phase; $6 \mathrm{~g}$ in cold phase) and averaged across each phase of the experiment for each replicate tank. Size-corrected tank mean consumption rates were tested across $\mathrm{CO}_{2}$ treatments with 1-way ANOVA.

\section{RESULTS}

\section{Yearling growth and condition}

No mortalities were associated with $\mathrm{CO}_{2}$ treatments (1 fish jumped from the tank). Averaged across all treatments, fish increased in length by $28.85 \pm$ $8.25 \mathrm{~mm}(\mathrm{SD})$ and increased in mass by $25.60 \pm 7.84 \mathrm{~g}$ (36.02 $\pm 11.22 \%$ over initial mass). There was no significant difference in growth rates across $\mathrm{CO}_{2}$ treatments $\left(g_{\mathrm{L}}: F_{3,42}=0.214, \mathrm{p}=0.886 ; g_{\mathrm{M}}: F_{3,42}=0.129\right.$, $\mathrm{p}=0.942$; Fig. 2). There was also no significant difference among $\mathrm{CO}_{2}$ treatments in $I_{\mathrm{C}}\left(F_{3,42}=0.777, \mathrm{p}=\right.$ $0.514)$ or $I_{\mathrm{H}}\left(F_{3,42}=1.255, \mathrm{p}=0.302\right)$ measured at the end of the experiment. 

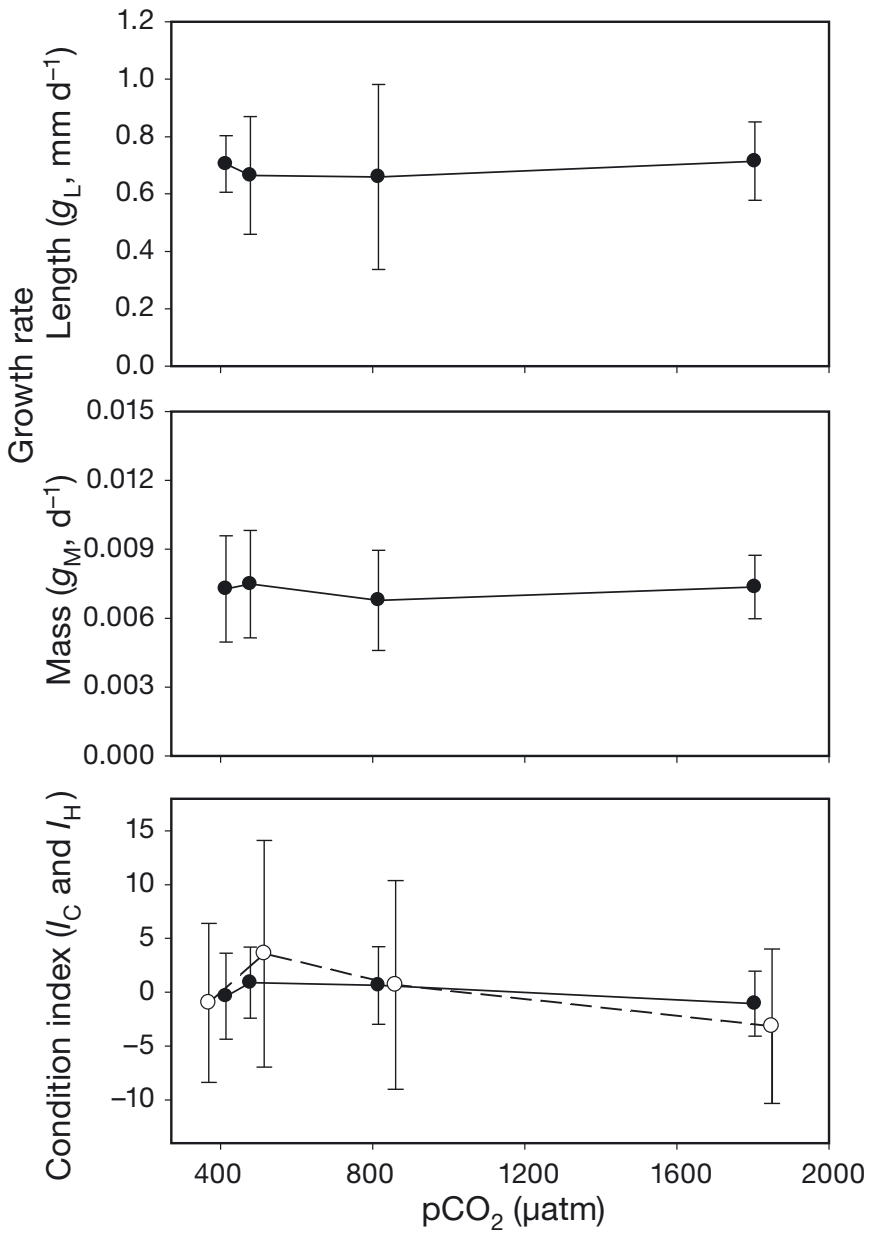

Fig. 2. Theragra chalcogramma. Growth and condition of yearling walleye pollock reared under elevated $\mathrm{CO}_{2}$ levels. Points are the means $( \pm \mathrm{SD})$ of fish pooled across 3 replicate tanks in each treatment. In the bottom panel, filled circles are wet mass condition factor $\left(I_{\mathrm{C}}\right)$; open circles are hepatosomatic index $\left(I_{\mathrm{H}}\right)$; overlapping points are offset for clarity

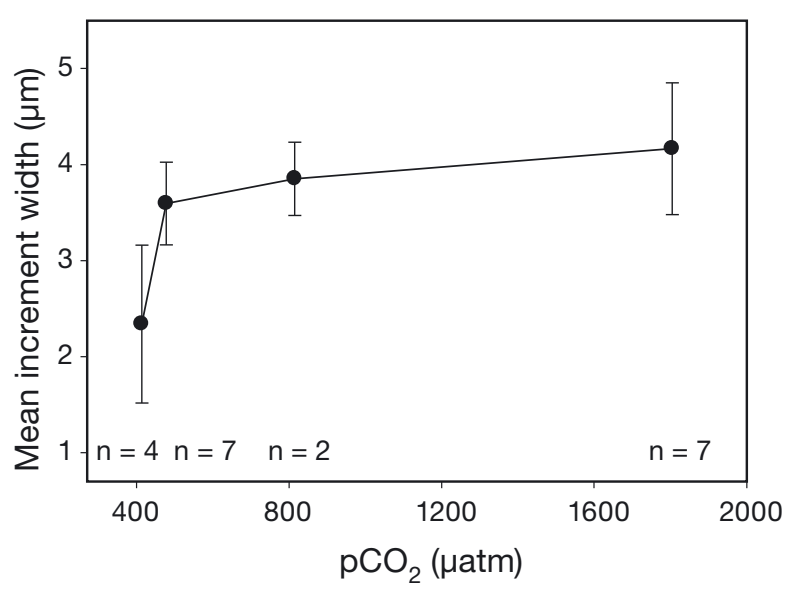

Fig. 3. Theragra chalcogramma. Mean otolith increment width of yearling walleye pollock reared under elevated $\mathrm{CO}_{2}$ levels. Points are the means $( \pm \mathrm{SD})$ of fish pooled across 3 replicate tanks in each treatment

0.59). There was no significant effect of $\mathrm{CO}_{2}$ treatment on otolith elemental composition (Table 2; all $F_{3,43}<1.90$, all $\mathrm{p}>0.10$ ) or elemental partition coefficients (all $F_{3,43}<2.10$, all $\mathrm{p}>0.11$ ) for any of the elemental ratios.

\section{Sub-yearling experiment: warm phase}

After the initial handling and acclimation period, there were only 5 mortalities among the 120 fish used in the experiment, and these were not clustered in any specific treatment or tank. During the warm phase of the experiment, $g_{\mathrm{L}}$ and $g_{\mathrm{M}}$ averaged $0.43 \pm$ $0.05(\mathrm{SD}) \mathrm{mm} \mathrm{d}^{-1}$ and $0.022 \pm 0.002 \mathrm{~d}^{-1}$, respectively, with faster fish growth at the 2 higher $\mathrm{CO}_{2}$ treat-

\section{Yearling otolith growth and composition}

Mean otolith increment width (MIW) averaged $3.57( \pm 0.891 \mathrm{SD})$ and ranged from 1.81 to $4.80 \mu \mathrm{m}$ $\mathrm{d}^{-1}$ across all treatments. There was a significant effect of $\mathrm{CO}_{2}$ treatment on $\operatorname{MIW}\left(F_{3,16}=7.59, \mathrm{p}=\right.$ 0.002). Post hoc comparisons indicated that MIW in the ambient $\mathrm{CO}_{2}$ treatment was lower than in all other treatments (Fig. 3), which did not vary significantly. Elemental composition of the water (Mg: $\mathrm{Ca}, \mathrm{Mn}: \mathrm{Ca}, \mathrm{Sr}: \mathrm{Ca}$, and $\mathrm{Ba}: \mathrm{Ca})$ did not vary among treatments (all $\mathrm{p}>$
Table 2. Theragra chalcogramma. Mean $( \pm \mathrm{SD})$ for otolith elemental ratios and partition coefficients of yearling walleye pollock exposed to elevated $\mathrm{CO}_{2}$. Otolith elemental ratios ( $\mathrm{Me}: \mathrm{Ca}_{\text {otolith }}$ ) are reported in $\mu \mathrm{mol} \mathrm{mol}^{-1}$ for Ba and $\mathrm{Mn}$ and $\mathrm{mmol} \mathrm{mol}^{-1}$ for $\mathrm{Mg}$ and Sr. Partition coefficients $\left(D_{\mathrm{Me}}\right)$ are calculated as $\mathrm{Me}: \mathrm{Ca}_{\text {otolith }} / \mathrm{Me}: \mathrm{Ca}_{\text {water }}$

\begin{tabular}{|lcccc|}
\hline & \multicolumn{5}{c|}{$\mathrm{CO}_{2}$ Treatment } \\
\cline { 2 - 5 } & $\begin{array}{c}\text { Ambient } \\
(414 \mu \mathrm{atm}) \\
\mathrm{n}=12\end{array}$ & $\begin{array}{c}\text { Low } \\
(478 \mu \mathrm{atm}) \\
\mathrm{n}=12\end{array}$ & $\begin{array}{c}\text { Medium } \\
(815 \mu \mathrm{atm}) \\
\mathrm{n}=11\end{array}$ & $\begin{array}{c}\text { High } \\
(1805 \mu \mathrm{\mu tm}) \\
\mathrm{n}=12\end{array}$ \\
\hline \multicolumn{2}{c}{} & & & \\
$\mathrm{Elemental} \mathrm{ratios}$ & & & \\
$\mathrm{Mg}: \mathrm{Ca}_{\text {otolith }}$ & $0.216 \pm 0.036$ & $0.203 \pm 0.028$ & $0.203 \pm 0.027$ & $0.216 \pm 0.044$ \\
$\mathrm{Mn}: \mathrm{Ca}_{\text {otolith }}$ & $15.975 \pm 9.395$ & $15.667 \pm 5.486$ & $16.402 \pm 7.042$ & $13.687 \pm 6.631$ \\
$\mathrm{Sr}: \mathrm{Ca}_{\text {otolith }}$ & $1.284 \pm 0.124$ & $1.273 \pm 0.123$ & $1.393 \pm 0.201$ & $1.257 \pm 0.104$ \\
$\mathrm{Ba}: \mathrm{Ca}_{\text {otolith }}$ & $1.051 \pm 0.239$ & $1.004 \pm 0.364$ & $1.339 \pm 0.455$ & $1.000 \pm 0.208$ \\
$\mathrm{Partition}$ coefficients & & & \\
$D_{\mathrm{Mg}}(\times 1000)$ & $0.042 \pm 0.007$ & $0.039 \pm 0.006$ & $0.039 \pm 0.005$ & $0.042 \pm 0.008$ \\
$D_{\mathrm{Mn}}$ & $0.596 \pm 0.351$ & $0.560 \pm 0.196$ & $0.574 \pm 0.246$ & $0.478 \pm 0.232$ \\
$D_{\mathrm{Sr}}$ & $0.151 \pm 0.015$ & $0.149 \pm 0.014$ & $0.164 \pm 0.024$ & $0.148 \pm 0.012$ \\
$D_{\mathrm{Ba}}$ & $0.352 \pm 0.080$ & $0.346 \pm 0.125$ & $0.430 \pm 0.146$ & $0.341 \pm 0.071$ \\
\hline
\end{tabular}


ments (Fig. 4). Taking into account variation in mean size at the beginning of the experiment (treated as a covariate), there was a significant effect of $\mathrm{CO}_{2}$ treatment on tank mean growth rates (ANCOVA, $g_{\mathrm{L}}$ : $\left.F_{3,7}=10.217, \mathrm{p}=0.006 ; g_{\mathrm{M}}: F_{3,7}=292.4, \mathrm{p}<0.001\right)$. There was no significant interaction between $\mathrm{CO}_{2}$ treatment and initial size on $g_{\mathrm{L}}$ or $g_{\mathrm{M}}$ (homogeneity of slopes among treatments, both $\mathrm{p}>0.30$ ). Post-hoc LSD tests indicated that growth rates in the 2 higher $\mathrm{CO}_{2}$ treatments were significantly greater than those in both of the lower $\mathrm{CO}_{2}$ treatments. In the 2 higher $\mathrm{CO}_{2}$ treatments, mean growth rates in length and mass, respectively, averaged 7.2 and $2.3 \%$ greater than in the 2 lower $\mathrm{CO}_{2}$ treatments.
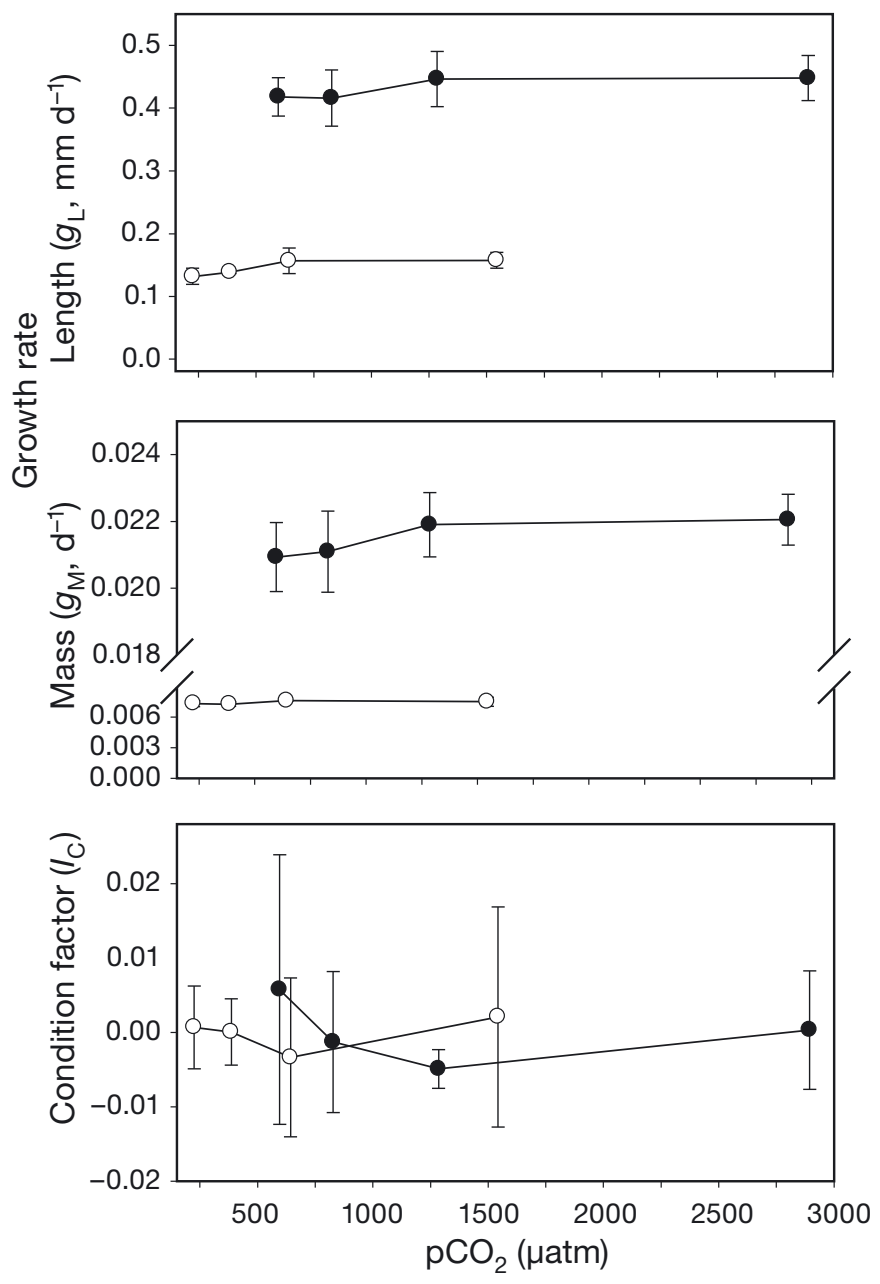

Fig. 4. Theragra chalcogramma. Growth and condition of sub-yearling walleye pollock reared under elevated $\mathrm{CO}_{2}$ levels. $\bullet$ : warm phase; 0 : cold phase. Growth rates were based on body size measurements at $2 \mathrm{wk}$ (warm phase) and $3 \mathrm{wk}$ (cold phase) intervals and averaged within replicate tanks. Points are the means $( \pm \mathrm{SD})$ of 3 replicate tanks in each treatment. Tank mean growth rates in length $\left(g_{\mathrm{L}}\right)$ and weightspecific growth $\left(g_{\mathrm{M}}\right)$ during the warm phase were corrected for differences in mean initial size
There was no effect of $\mathrm{CO}_{2}$ treatment on wet weight condition factor following $12 \mathrm{wk}$ of rearing. Mean $I_{\mathrm{C}}$ did not differ among $\mathrm{pH}$ treatments (ANOVA, $F_{3,8}=0.483, \mathrm{p}=0.703$ ). Tank mean $I_{\mathrm{C}}$ was not correlated with either $g_{\mathrm{L}}(\mathrm{r}=0.005, \mathrm{p}=0.987)$ or $g_{\mathrm{M}}(\mathrm{r}=-0.156, \mathrm{p}=0.625)$.

$C$ for each tank measured throughout the warm phase of the experiment did not differ significantly across $\mathrm{CO}_{2}$ treatments (Fig. 5; ANOVA, $F_{3,8}=1.281$, $\mathrm{p}=0.345)$. However, across all $\mathrm{CO}_{2}$ treatments, $C$ tended to be higher in tanks with higher mean growth rates $\left(g_{\mathrm{L}}: \mathrm{r}=0.519, \mathrm{p}=0.084 ; g_{\mathrm{M}}: \mathrm{r}=0.574\right.$, $\mathrm{p}=0.051$ ), suggesting that higher growth rates in the higher $\mathrm{CO}_{2}$ treatments were accomplished via higher consumption rates.

\section{Sub-yearling experiment: cold phase}

Growth rates during the cold phase were lower than during the warm phase of the experiment, with $g_{\mathrm{L}}$ and $g_{\mathrm{M}}$ averaging $0.146 \pm 0.031(\mathrm{SD}) \mathrm{mm} \mathrm{d}^{-1}$ and $0.007 \pm 0.002 \mathrm{~d}^{-1}$, respectively. Although there was a trend toward faster growth in the higher $\mathrm{CO}_{2}$ treatments, this result was not significant (Fig. 4; ANOVA, $\left.g_{\mathrm{L}}: F_{3,8}=2.707, \mathrm{p}=0.116 ; g_{\mathrm{M}}: F_{3,8}=0.8, \mathrm{p}=0.511\right)$. There was no effect of $\mathrm{CO}_{2}$ treatment on $I_{\mathrm{C}}$ at the end of the cold phase. Mean $I_{\mathrm{C}}$ did not differ among $\mathrm{CO}_{2}$ treatments (ANOVA, $F_{3,8}=0.167, \mathrm{p}=0.915$ ). Tank mean $I_{\mathrm{C}}$ was not correlated with growth rates $\left(g_{\mathrm{L}}: \mathrm{r}=\right.$ $-0.172, \mathrm{p}=0.593 ; g_{\mathrm{M}}: \mathrm{r}=-0.150, \mathrm{p}=0.641$ ).

Differences in body size among $\mathrm{CO}_{2}$ treatments generated by differences in growth rates during the warm phase of the experiment carried over to the end

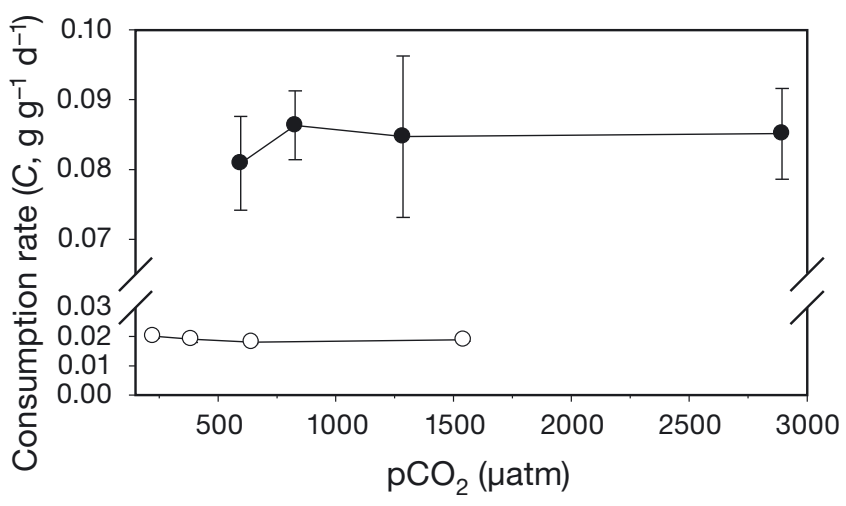

Fig. 5. Theragra chalcogramma. Consumption rates of subyearling walleye pollock reared under elevated $\mathrm{CO}_{2}$ levels. -: warm phase; O: cold phase. Consumption rates were measured once per week during both phases of the experiment and standardized to a common mean fish mass $(2 \mathrm{~g}$ warm phase; $6 \mathrm{~g}$ cold phase). Points are the means $( \pm \mathrm{SD})$ of 3 replicate tanks in each treatment 
of the cold phase. There were slight differences in size among $\mathrm{CO}_{2}$ treatments following 29 wk of rearing (warm and cold phases combined), during which fish had more than doubled in length and increased 10fold in mass (ANCOVA tank mean final size with tank mean initial size as covariate, length: $F_{3,7}=3.97, \mathrm{p}=$ 0.061 ; mass: $\left.F_{3,7}=4.47, \mathrm{p}=0.047\right)$. The mean size of fish in the medium $\mathrm{CO}_{2}$ treatment tanks (corrected for variation in initial sizes) was $3.47 \mathrm{~mm}$ and $0.61 \mathrm{~g}$ greater than the fish in the ambient $\mathrm{CO}_{2}$ treatment.

$C$ for each tank measured throughout the cold phase of the experiment did not differ significantly across $\mathrm{CO}_{2}$ treatments, but there was a trend toward higher $C$ in the ambient treatment (ANOVA, $F_{3,8}=$ $3.34, \mathrm{p}=0.077)$. Across $\mathrm{CO}_{2}$ treatments, $C$ during the cold phase was not correlated with either increases in length $(\mathrm{r}=-0.294, \mathrm{p}=0.354)$ or mass $(\mathrm{r}=-0.376$, $\mathrm{p}=0.229$ ).

\section{DISCUSSION}

There is significant concern that ocean acidification, caused by the dissolution of anthropogenically released $\mathrm{CO}_{2}$ into the ocean, will cause major disruptions to the productivity and functioning of highlatitude marine ecosystems (Cooley \& Doney 2009, Fabry et al. 2009). Increased $\mathrm{CO}_{2}$ and decreased $\mathrm{pH}$ is known to influence a variety of physiological and behavioral processes in a wide range of marine organisms (Fabry et al. 2008, Munday et al. 2009b), but as of yet there is little understanding of relative sensitivities among species within broad taxonomic guilds. In laboratory experiments, we found juvenile walleye pollock to be resilient to the direct effects of elevated environmental $\mathrm{CO}_{2}$; growth rates of yearlings and sub-yearlings were not negatively affected by elevated levels of environmental $\mathrm{CO}_{2}$, even under prolonged exposures. This resiliency was apparent under seasonally warm and cold conditions, and walleye pollock appeared resilient to conditions well beyond the range of $\mathrm{CO}_{2}$ and $\mathrm{pH}$ predicted for the North Pacific Ocean and Bering Sea over the next century. While the conclusions drawn here are derived from experiments with juveniles, a similar resiliency was observed in companion experiments with egg and larval stages of walleye pollock ( $\mathrm{T}$. Hurst unpubl.). However, ocean acidification has been shown to induce other physiological and behavioral responses that have yet to be evaluated in this and other North Pacific resource species.

We conducted 2 independent experiments to evaluate different aspects of potential responses of juve- nile walleye pollock to elevated $\mathrm{CO}_{2}$ levels. A shortterm $(6 \mathrm{wk})$, acute exposure experiment with yearling walleye pollock was conducted first to evaluate general sensitivity of the species to elevated $\mathrm{CO}_{2}$ and examine otolith deposition responses. Concern has been expressed that the resiliency observed in fishes to simulated ocean acidification may be limited in scope and that most ocean acidification experiments have been of insufficient duration to capture potential cumulative effects of chronic exposures to elevated $\mathrm{CO}_{2}$ conditions (Riebesell et al. 2010, but see Melzner et al. 2009a). To examine the potential for longer-term effects, a second experiment was conducted with smaller sub-yearlings. In addition to simply extending the duration of exposure, the longterm experiment included seasonally-reflective warm and cold phases. Most ocean acidification experiments have been conducted on the warmer end of the species' thermal range (but see Walther et al. 2011), in some cases testing organisms at temperatures near or above current exposure limits (e.g. Munday et al. 2009a). However, it is important to recognize that arctic and subarctic fishes, and species living in highly seasonal environments, will continue to be exposed to low winter temperatures. It has been hypothesized that ocean acidification may restrict the 'thermal window' of fishes by reducing physiological performance at both high and low temperatures (Pörtner 2010). Low temperatures are known to reduce the effectiveness of ion balance at both the cellular and organismal level and depress feeding ability (Ibarz et al. 2010). The degree to which low temperature responses interact with, or exacerbate the effects of, other physiochemical stressors is largely unknown (Hurst 2007). For walleye pollock, it was important to determine whether the effects of ocean acidification are more pronounced at the upper or lower end of the thermal range, as potential interactions with low temperature stress would disproportionately affect the high-latitude populations in the Gulf of Alaska and Bering Sea regions which support major commercial fisheries. Additional experiments evaluated responses of eggs and larvae, which may be expected to be more sensitive to the effects of ocean acidification (Ishimatsu et al. 2008).

\section{Growth energetics}

Survival and growth rates of sub-yearling and yearling walleye pollock were not negatively affected by exposure to elevated levels of environmental $\mathrm{CO}_{2}$ and reduced $\mathrm{pH}$. This resiliency appears to 
apply across a broad range of $\mathrm{CO}_{2}$ levels and does not appear to be compromised by the physiological constraints imposed by low temperatures. The results observed here for walleye pollock are generally consistent with hypothesized (Michaelidis et al. 2007, Melzner et al. 2009b) and observed responses in other juvenile fishes (Ishimatsu et al. 2008). In intensive aquaculture settings, negative growth effects were not seen in juvenile Atlantic cod Gadus morhua at $\mathrm{pH}$ as low as 7.1 (Foss et al. 2006) and were only seen in juvenile spotted wolffish Anarhichas minor at extreme pH levels $(<6.5$; Foss et al. 2003). In fact, during the warm phase of our sub-yearling experiment, growth rates were slightly (but significantly) higher in the higher $\mathrm{CO}_{2}$ treatments, a pattern also observed in several other studies (Munday et al. 2009c, Frommel et al. 2012).

While it is notable that we did not see negative effects of elevated $\mathrm{CO}_{2}$ on somatic growth rates of walleye pollock, measurement of growth rates does not provide a complete picture of potential energetic effects of ocean acidification (Cohen \& Holcomb 2009, Nowicki et al. 2012). Fish have the capacity to increase feeding in response to energetic stress. While most studies of compensatory feeding have examined responses to reduced energy stores following periods of food deprivation (Ali et al. 2003), other studies have documented elevated feeding rates in response to increased metabolic costs (Hurst \& Conover 2001). In the experiment with sub-yearling walleye pollock, measurement of consumption rates allowed us to confirm that fish were not maintaining growth rates in the face of increased metabolic demands through compensatory feeding. Similar conclusions were reached in experiments where spotted wolffish and Pacific cod Gadus macrocephalus exhibited similar growth efficiencies across the range of $\mathrm{CO}_{2}$ concentrations used here (Foss et al. 2003, T. Hurst unpubl.). Further, there was no effect of rearing $\mathrm{CO}_{2}$ on condition factor of sub-yearling or yearling walleye pollock, suggesting that significant amounts of energy were not being diverted from accumulation of reserves in order to maintain adequate growth (Hurst et al. 2005). The metabolic costs of swimming activity represent the final piece of the energetic budget that could be adjusted to compensate for elevated metabolic costs. Although activity levels were not explicitly measured in these experiments, routine observations did not suggest overall differences in activity levels of fish in the different $\mathrm{CO}_{2}$ treatments. While several experiments have demonstrated some behavioral consequences of ocean acidification (Munday et al. 2009b, Dixson et al.
2010), there have been no documented cases of compensatory reductions in swimming activity (Nowicki et al. 2012, Maneja et al. in press) or reduced maximum swimming capacity (Melzner et al. 2009a, Munday et al. 2009a) of fish reared under elevated environmentally relevant $\mathrm{CO}_{2}$ levels. For these species, if exposure to environmental hypercapnia does in fact induce an ongoing metabolic expense, the magnitude of that expenditure appears to be negligible in the context of the overall energy budget.

\section{Otolith responses}

Having an internal skeleton composed primarily of calcium phosphate, marine fishes are generally assumed to be less sensitive to the effects of ocean acidification than invertebrates which precipitate external skeletons of calcium carbonate (Cooley \& Doney 2009, Kroeker et al. 2010). Juvenile and adult fishes have highly developed systems for acid-base regulation and gas exchange. The physiological responses to environmental hypercapnia in fishes are well described and include an active increase in extracellular $\mathrm{HCO}_{3}{ }^{-}$, which minimizes variance in blood pH (Melzner et al. 2009b). This increase in internal buffering was observed in yearling walleye pollock (E. R. Fernandez unpubl.) and has been suggested as the driver of changes in otolith calcification rates observed in some species under ocean acidification (Checkley et al. 2009, Munday et al. 2011b). Despite limited sample sizes, analysis of daily increment widths in otoliths of yearling walleye pollock demonstrated that the ocean acidification effects on otoliths are not limited to larval stages. However, as yearling walleye pollock in this experiment were reared under elevated $\mathrm{CO}_{2}$ levels for $6 \mathrm{wk}$, it is unclear whether such an increased deposition rate response would persist under prolonged exposure to elevated $\mathrm{CO}_{2}$. The ultimate consequences of increased deposition rates (and larger otolith sizes) for otolith function in hearing and orientation in temperate fishes are still unknown. Reduced (or reversed) responses to auditory cues were observed in clownfish Amphiprion percula (Simpson et al. 2011), a species in which there were no apparent differences in otolith size or symmetry in response to environmental hypercapnia (Munday et al. 2011b). Alternatively, the altered behavioral response to auditory cues in clownfish may be related to an alteration of the activity of the GABA-A receptor, as this receptor has also been linked to ocean acidification-induced behavioral responsiveness to olfactory stimuli (Dixson et al. 
2010, Nilsson et al. 2012). Alteration of $\mathrm{Cl}^{-}$and/or $\mathrm{HCO}_{3}{ }^{-}$gradients over neuronal membranes, which result from acid-balance compensation for increased blood and tissue $\mathrm{CO}_{2}$, appear to stimulate an excitatory neuronal response rather than the normal inhibitory response, thus resulting in abnormal behaviors (Nilsson et al. 2012). Interestingly, whereas the physiological responses to hypercapnia of elevated blood $\mathrm{HCO}_{3}{ }^{-}$may have altered neuroreceptor function and precipitation rate of the otolith matrix, there was no concurrent change in the elemental composition of otoliths of walleye pollock or clownfish (Munday et al. 2011b).

\section{Population exposure history}

A significant unknown in predicting the consequences of ocean acidification for marine communities is the potential for acclimation or evolutionary adaptation to new climate conditions (but see Parker et al. 2011, Miller et al. in press). In interpreting the results from laboratory exposures to elevated $\mathrm{CO}_{2}$ for predicting species' responses to ocean acidification, it is critical to consider life history and natural patterns of environmental variation experienced by the species or population (Hofmann et al. 2011, McElhaney \& Busch in press). For example, marine species or populations that naturally experience episodic (diurnal or seasonal) or chronic exposures (near seafloor $\mathrm{CO}_{2}$ vents or seeps) to high $\mathrm{CO}_{2}$ may be less sensitive to increases attributable to anthropogenic $\mathrm{CO}_{2}$ releases (Munday et al. 2009a, Hofmann et al. 2010). In this study, we found that juvenile walleye pollock captured from Puget Sound were resilient to even prolonged exposure to markedly elevated $\mathrm{CO}_{2}$ levels. Some deep areas of Puget Sound currently experience $\mathrm{pH}$ levels below 7.7 due to reduced mixing rates and natural or anthropogenically enhanced microbial respiration (Feely et al. 2010). Prior exposure of Puget Sound walleye pollock to elevated $\mathrm{CO}_{2}$ levels may have preconditioned the population (via either acclimation or adaptation), contributing to the observed resiliency to the effects of high $\mathrm{CO}_{2}$ (Miller et al. 2012). However, seasonal upwelling and respiration of exported organic matter over the shelf can also create low $\mathrm{pH}$ conditions in the 7.7 to 7.8 range in summer and fall in the Gulf of Alaska and the Bering Sea (Mathis et al. in press). Further, Puget Sound walleye pollock were resilient to $\mathrm{CO}_{2}$ levels far exceeding those anticipated for either region over the next 100 yr. Finally, Bering Sea and Gulf of Alaska walleye pollock populations would be expected to undergo similar adaptation or acclimation to long-term changes in environmental $\mathrm{CO}_{2}$ (Hofmann et al. 2010). Hence, it is likely that the general resiliency observed for Puget Sound walleye pollock applies equally to Alaskan populations facing ocean acidification.

\section{CONCLUSIONS}

Ocean acidification is predicted to have significant effects on high-latitude ecosystems (Fabry et al. 2009). Several recent studies have documented negative direct effects of elevated $\mathrm{CO}_{2}$ on developing fish eggs and larvae (Baumann et al. 2012, Frommel et al. 2012). However, ocean acidification did not appear to negatively affect the growth energetics of juvenile walleye pollock. Throughout our experiments, there was no evidence that exposure to elevated $\mathrm{CO}_{2}$ reduced growth or condition, or required elevated consumption rates to offset increased metabolic costs. In fact, as has been seen in other studies (Munday et al. 2009c, Frommel et al. 2012), a trend toward higher growth rates in treatments with higher $\mathrm{CO}_{2}$ levels among sub-yearlings was observed. Even in this case, the magnitude of the $\mathrm{CO}_{2}$ effect was smaller than those induced in marine gadids by environmentally relevant variation in temperature (Hurst et al. 2010) or prey availability (Laurel et al. 2011). Hence, the results presented here, and parallel work on eggs and larval stages (T. Hurst unpubl.) suggest that production of walleye pollock appears more resilient to the direct effects of ocean acidification than other aspects of long-term climate variation (Munday et al. 2009a, Hunt et al. 2011, Mueter et al. 2011). Additional work should be focused on the potential consequences of ocean acidification-induced sensory impairment and the indirect consequences of food web alterations.

Acknowledgements. M. Spencer and S. Haines assisted with fish collections. M. Ottmar, W. Clerf, C. Danley, S. Haines, and C. Magel assisted with maintenance of experimental fish. C. Magel assisted with system maintenance and $\mathrm{CO}_{2}$ monitoring throughout the experiments. C. Ryer, P. McElhaney, and 3 anonymous reviewers provided valuable comments on this manuscript. Some of this work was completed in partial fulfillment of E.R.F.'s M.S. thesis at the University of Alaska at Fairbanks. This project was funded by a grant from the Pollock Conservation Cooperative Research Center to J.T.M. and grants to T.P.H. from NOAA's Ocean Acidification Program. E.R.F. was supported with a graduate research fellowship from the Rasmuson Foundation and a Markham Award from Oregon State University's Hatfield Marine Science Center. C.M.S. and E.F.A. were supported by a National Science Foundation Research Experience for Undergraduates internship under award OCE-1004947 to the Hatfield Marine Science Center. Reference to trade 
names does not imply endorsement by the National Marine Fisheries Service. The findings and conclusions in this paper are those of the authors and do not necessarily represent the views of the National Marine Fisheries Service.

\section{LITERATURE CITED}

Al-Horani F, Al-Moghrabi S, de Beer D (2003) The mechanism of calcification and its relation to photosynthesis and respiration in the scleractinian coral Galaxea fascicularis. Mar Biol 142:419-426

Ali M, Nicieza A, Wootton RJ (2003) Compensatory growth in fishes: a response to growth depression. Fish Fish 4: 147-190

Baumann H, Talmage SC, Gobler CJ (2012) Reduced early life growth and survival in a fish in direct response to increased carbon dioxide. Nat Clim Change 2:38-41

Blackwell BG, Brown ML, Willis DW (2000) Relative weight (Wr) status and current use in fisheries assessment and management. Rev Fish Sci 8:1-44

Brodeur RD, Wilson MT (1996) A review of the distribution, ecology, and population dynamics of age-0 walleye pollock in the Gulf of Alaska. Fish Oceanogr 5(Suppl1): 148-166

Byrne RH, Meckling S, Feely RA, Liu Z (2010) Direct observations of basin-wide acidification of the North Pacific Ocean. Geophys Res Lett 37:L02601, doi:10.1029/2009GL 040999

Checkley DM, Dickson AG, Takahashi M, Radich JA, Eisenkolb N, Asch R (2009) Elevated $\mathrm{CO}_{2}$ enhances otolith growth in young fish. Science $324: 1683$

> Cohen AL, Holcomb M (2009) Why corals care about ocean acidification: uncovering the mechanism. Oceanography 22:118-127

> Cooley SR, Doney SC (2009) Anticipating ocean acidification's economic consequences for commercial fisheries. Environ Res Lett 4:024007, doi:10.1088/1748-9326/4/2/ 024007

> Denman K, Christian JR, Steiner N, Portner HO, Nojiri Y (2011) Potential impacts of future ocean acidification on marine ecosystems and fisheries: current knowledge and recommendations for future research. ICES J Mar Sci 68: 1019-1029

> DiMaria RA, Miller JA, Hurst TP (2010) Temperature and growth effects on otolith elemental chemistry of larval Pacific cod, Gadus macrocephalus. Environ Biol Fishes 89:453-462

Dixson DL, Munday PL, Jones GP (2010) Ocean acidification disrupts the innate ability of fish to detect predator olfactory cues. Ecol Lett 13:68-75

Fabry VJ, Seibel BA, Feely RA, Orr JC (2008) Impacts of ocean acidification on marine fauna and ecosystem processes. ICES J Mar Sci 65:414-432

Fabry VJ, McClintock JB, Mathis JT, Grebmeier JM (2009) Ocean acidification at high latitudes: the bellwether. Oceanography 22:160-171

Feely RA, Sabine CL, Lee K, Berelson W, Kleypas J, Fabry VJ, Millero FJ (2004) Impact of anthropogenic $\mathrm{CO}_{2}$ on the $\mathrm{CaCO}_{3}$ system in the oceans. Science 305:362-366

> Feely RA, Alin SR, Newton J, Sabine CL and others (2010) The combined effects of ocean acidification, mixing, and respiration on $\mathrm{pH}$ and carbonate saturation in an urbanized estuary. Estuar Coast Shelf Sci 88:442-449

Folkvord A, Otterå H (1993) Effects of initial size distribu- tion, day length, and feeding frequency on growth, survival, and cannibalism in juvenile Atlantic cod (Gadus morhua L). Aquaculture 114:243-260

> Foss A, Rosnes BA, Oiestad V (2003) Graded environmental hypercapnia in juvenile spotted wolffish (Anarhichas minor Olafsen): effects on growth, food conversion efficiency and nephrocalcinosis. Aquaculture 220:607-617

- Foss A, Kristensen T, Atland A, Hustveit H, Hovland H, Ofsti A, Imsland AK (2006) Effects of water reuse and stocking density on water quality, blood physiology and growth rate of juvenile cod (Gadus morhua). Aquaculture 256: 255-263

Frommel AY, Maneja R, Lowe D, Malzahn AM and others (2012) Severe tissue damage in Atlantic cod larvae under increasing ocean acidification. Nat Clim Change 2:42-46

Gaetani GA, Cohen AL (2006) Element partitioning during precipitation of aragonite from seawater: a framework for understanding paleoproxies. Geochim Cosmochim Acta 70:4617-4634

> Hofmann GE, Barry JP, Edmunds PJ, Gates RD, Hutchins DA, Klinger T, Sewell MA (2010) The effect of ocean acidification on calcifying organisms in marine ecosystems: an organism-to-ecosystem perspective. Annu Rev Ecol Evol Syst 41:127-147

> Hofmann GE, Smith JE, Johnson KS, Send U and others (2011) High-frequency dynamics of ocean pH: a multiecosystem comparison. PLoS ONE 6:e28983

> Hunt GL, Coyle KO, Eisner LB, Farley EV and others (2011) Climate impacts on eastern Bering Sea foodwebs: a synthesis of new data and an assessment of the Oscillating Control Hypothesis. ICES J Mar Sci 68:1230-1243

> Hurst TP (2007) Causes and consequences of winter mortality in fishes. J Fish Biol 71:315-345

Hurst TP, Conover DO (2001) Activity-related constraints on overwintering young-of-the-year striped bass (Morone saxatilis). Can J Zool 79:129-136

> Hurst TP, Spencer ML, Sogard SM, Stoner AW (2005) Compensatory growth, energy storage and behavior of juvenile Pacific halibut Hippoglossus stenolepis following a thermally induced growth reduction. Mar Ecol Prog Ser 293:233-240

Hurst TP, Laurel BJ, Ciannelli L (2010) Ontogenetic patterns and temperature-dependence of growth rate in early life stages of Pacific cod (Gadus macrocephalus). Fish Bull 108:382-392

Ibarz A, Padros F, Gallardo MA, Fernandez-Borras J, Blasco J, Tort L (2010) Low-temperature challenges to gilthead sea bream culture: review of cold-induced alterations and 'Winter Syndrome'. Rev Fish Biol Fish 20:539-556

Ishimatsu A, Hayashi M, Kikkawa T (2008) Fishes in high$\mathrm{CO}_{2}$, acidified oceans. Mar Ecol Prog Ser 373:295-302

Kroeker KJ, Kordas RL, Crim RN, Singh GG (2010) Metaanalysis reveals negative yet variable effects of ocean acidification on marine organisms. Ecol Lett 13:1419-1434

> Laurel BJ, Hurst TP, Ciannelli L (2011) An experimental examination of temperature interactions in the matchmismatch hypothesis for Pacific cod larvae. Can J Fish Aquat Sci 68:51-61

Lewis E, Wallace DWR (1998) Program developed for $\mathrm{CO}_{2}$ system calculations. US Department of Energy Report ORNL/CDIAC-105. Carbon Dioxide Information Analysis Center, Oak Ridge National Laboratory, Oak Ridge, TN

$>$ Livingston PA (1993) Importance of predation by groundfish, marine mammals and birds on walleye pollock Theragra chalcogramma and Pacific herring Clupea pal- 
lasi in the eastern Bering Sea. Mar Ecol Prog Ser 102: 205-215

Maneja R, Frommel AY, Browman HI, Clemmensen C and others (in press) The swimming kinematics of larval Atlantic cod, Gadus morhua L. are resilient to elevated $p \mathrm{CO}_{2}$. Mar Biol, doi:10.1007/s00227-012-2054-y

Mathis JT, Cross JN, Bates NR (2011a) The role of ocean acidification in systemic carbonate mineral suppression in the Bering Sea. Geophys Res Lett 38:19602, doi:10. 1029/2011GL048884

Mathis JT, Cross JN, Bates NR (2011b) Coupling primary production and terrestrial runoff to ocean acidification and carbonate mineral suppression in the Eastern Bering Sea. J Geophys Res 116:C02030, doi:10.1029/2010JC 006453

Mathis JT, Evans W, Sabine CL, Juranek LW and others (in press) The physical and biological controls on $\mathrm{CO}_{2}$ fluxes and carbonate mineral saturation states in the northern Gulf of Alaska. J Geophys Res

McElhaney $\mathrm{P}$, Busch DS (in press) Appropriate $p \mathrm{CO}_{2}$ treatments in ocean acidification experiments. Mar Biol

> Melzner F, Gobel S, Langenbuch M, Gutowska MA, Pörtner HO, Lucassen M (2009a) Swimming performance in Atlantic cod (Gadus morhua) following long-term (4-12 months) acclimation to elevated seawater $\mathrm{P}\left(\mathrm{CO}_{2}\right)$. Aquat Toxicol 92:30-37

Melzner F, Gutowska MA, Langenbuch M, Dupont S and others (2009b) Physiological basis for high $\mathrm{CO}_{2}$ tolerance in marine ectothermic animals: pre-adaptation through lifestyle and ontogeny? Biogeosciences 6:2313-2331

Michaelidis B, Spring A, Pörtner HO (2007) Effects of longterm acclimation to environmental hypercapnia on extracellular acid-base status and metabolic capacity in Mediterranean fish Sparus aurata. Mar Biol 150:1417-1429

Miller JA (2009) The effects of temperature and water concentration on the otolith incorporation of barium and manganese in black rockfish Sebastes melanops. J Fish Biol 75:39-60

Miller GM, Watson SA, Donelson JM, McCormick MI, Munday PL (in press) Parental environment mediates impacts of increased carbon dioxide on a coral reef fish. Nat Clim Change

$>$ Morse JW, Bender ML (1990) Partition-coefficients in calcite: examination of factors influencing the validity of experimental results and their application to natural systems. Chem Geol 82:265-277

Mueter FJ, Bond NA, Ianelli JN, Hollowed AB (2011) Expected declines in recruitment of walleye pollock (Theragra chalcogramma) in the eastern Bering Sea under future climate change. ICES J Mar Sci 68:1284-1296

> Munday PL, Crawley NE, Nilsson GE (2009a) Interacting effects of elevated temperature and ocean acidification on the aerobic performance of coral reef fishes. Mar Ecol Prog Ser 388:235-242

Munday PL, Dixson DL, Donelson JM, Jones GP, Pratchett MS, Devitsina GV, Doving KB (2009b) Ocean acidification impairs olfactory discrimination and homing ability of a marine fish. Proc Natl Acad Sci USA 106:1848-1852

Munday PL, Donelson JM, Dixson DL, Endo GGK (2009c) Effects of ocean acidification on the early life history of a tropical marine fish. Proc R Soc Lond B Biol Sci 276: 3275-3283

Editorial responsibility: Christine Paetzold, Oldendorf/Luhe, Germany
Munday PL, Gagliano M, Donelson JM, Dixson DL, Thorrold SR (2011a) Ocean acidification does not affect the early life history development of a tropical marine fish. Mar Ecol Prog Ser 423:211-221

> Munday PL, Hernaman V, Dixson DL, Thorrold SR (2011b) Effect of ocean acidification on otolith development in larvae of a tropical marine fish. Biogeosciences 8: 1631-1641

Nilsson GE, Dixson DL, Domenici P, McCormick MI, Sorensen C, Watson SA, Munday PL (2012) Near-future carbon dioxide levels alter fish behaviour by interfering with neurotransmitter function. Nat Clim Change 2: 201-204

> Nowicki JP, Miller GM, Munday PL (2012) Interactive effects of elevated temperature and $\mathrm{CO}_{2}$ on foraging behavior of juvenile coral reef fish. J Exp Mar Biol Ecol 412:46-51

> Orr JC, Fabry VJ, Aumont O, Bopp L and others (2005) Anthropogenic ocean acidification over the twenty-first century and its impact on calcifying organisms. Nature 437:681-686

> Parker LM, Ross PM, O'Connor WA (2011) Populations of the Sydney rock oyster, Saccostrea glomerata, vary in response to ocean acidification. Mar Biol 158:689-697

> Pörtner HO (2010) Oxygen- and capacity-limitation of thermal tolerance: a matrix for integrating climate-related stressor effects in marine ecosystems. J Exp Biol 213: 881-893

Pörtner HO, Langenbuch M, Reipschläger A (2004) Biological impact of elevated ocean $\mathrm{CO}_{2}$ concentrations: lessons from animal physiology and earth history. J Oceanogr 60: $705-718$

Riebesell U, Fabry VJ, Hansson L, Gattuso JP (eds) (2010) Guide to best practices for ocean acidification research and data reporting. Publications Office of the European Union, Luxembourg

Ries JB, Cohen AL, McCorkle DC (2009) Marine calcifiers exhibit mixed responses to $\mathrm{CO}_{2}$-induced ocean acidification. Geology 37:1131-1134

Sabine CL, Feely RA, Gruber N, Key RM and others (2004) The oceanic sink for anthropogenic $\mathrm{CO}_{2}$. Science 305: 367-371

Simpson SD, Munday PL, Wittenrich ML, Manassa R, Dixson DL, Gagliano M, Yan HY (2011) Ocean acidification erodes crucial auditory behaviour in a marine fish. Biol Lett 7:917-920

Smart TI, Duffy-Anderson JT, Horne JK, Farley EV, Wilson CD, Napp JM (2012) Influence of environment on walleye pollock eggs, larvae, and juveniles in the southeastern Bering Sea. Deep-Sea Res II 65-70:196-207

Steinacher M, Joos F, Frolicher TL, Plattner GK, Doney SC (2009) Imminent ocean acidification in the Arctic projected with the NCAR global coupled carbon cycleclimate model. Biogeosciences 6:515-533

> Walther K, Sartoris FJ, Portner H (2011) Impacts of temperature and acidification on larval calcium incorporation of the spider crab Hyas araneus from different latitudes $\left(54^{\circ}\right.$ vs. $\left.79^{\circ} \mathrm{N}\right)$. Mar Biol 158:2043-2053

Yamamoto-Kawai M, McLaughlin FA, Carmack EC, Nishino S, Shimada K (2009) Aragonite undersaturation in the Arctic Ocean: effects of ocean acidification and sea ice melt. Science 326:1098-1100

Submitted: August 16, 2012; Accepted: October 31, 2012 Proofs received from author(s): November 27, 2012 